Triassic and Jurassic sediments have been described by Birkelund \& Perch-Niel$\operatorname{sen}(1969 a \& b)$.

A large collection of trace fossils of the Middle Jurassic "Yellow Series" was made by one of the parties. This material indicates shallow marine and delta conditions of sedimentation for these beds.

A preliminary study of the sills and dykes in the sediments around Werner Bjerge has been started. The dykes can vary in thickness from a few $\mathrm{cm}$ to $15 \mathrm{~m}$ and the sills from one to over a hundred metres near Ørsted Dal. The direction of the dykes was found to be variable, but large numbers could be observed with trends of $10^{\circ}, 80^{\circ}$ and $125^{\circ}$.

\title{
References
}

Birkelund, T. \& Perch-Nielsen, K. 1969a: Field mapping in Upper Palaeozoic and Mesozoic sediments of Scoresby Land and Jameson Land. Rapp. Grønlands geol. Unders. 19, 53-57.

Birkelund, T. \& Perch-Nielsen, K. 1969b: Field observations in Upper Palaeozoic and Mesozoic sediments of Scoresby Land and Jameson Land. Rapp. Gronlands geol. Unders. 21, 21-35.

Kempter, E. 1961 : Die Jungpaläozoischen Sedimente von Süd Scoresby Land. Meddr Gronland $164,1$. Witzig, E. 1954: Stratigraphische und tektonische Beobachtungen in der Mesters Vig Region (Scoresby Land, Nordostgrönland). Meddr Gronland 72, 5.

\section{OBSERVATIONS ON THE PRECAMBRIAN ROCKS OF SCANDINAVIA AND LABRADOR AND THEIR IMPLICATIONS FOR THE INTERPRETATION OF THE PRECAMBRIAN OF GREENLAND}

\section{Bridgwater}

During the summer of 1969 the writer visited two of the main North Atlantic Shield areas outside Greenland as a guest of the Geological Surveys of Sweden, Finland and Canada. The visit to Scandinavia was organised as a field excursion in conjunction with the I. U. G. S. Subcommission on Precambrian Stratigraphy meeting held in Stockholm at the beginning of June. I would like to thank Professors Rankama, Simonen and Welin for their arrangements, and my companions during the field excursion for stimulating discussion of Precambrian problems. The visit to northern Labrador was initiated by the Geological Surveys of Greenland and Canada as part of a programme to compare the geology on each side of the Davis Strait. I would like to thank Dr F. C. Taylor whose party Dr B. F. Windley (Leicester University) and I joined in Labrador for his help in planning and carrying out this part of the program- 
me. It is to be hoped that this was only a start to cooperative ventures between the two Surveys and that a member of the GSC staff will be able to join a GGU field party in West Greenland. After leaving the GSC party the writer was joined by Dr N. Westoll (Queens University, Kingston) to work further south along the Labrador coast. This was made possible through the kindness of Drs E. P. Wheeler and S. A. Morse who provided logistical support and considerable unpublished information about the Nain district, and through the courtesy of Drs. S. Gandhi, P. Grimley and A. Beavan of the British Newfoundland Exploration Co. who provided transport, hospitality and geological information in the Makkovik and Seal Lake districts. Finally I would like to thank the staffs of the Iron Ore Co. of Canada and the McGill University Sub-Arctic Station for their help in visiting the marginal rocks of the Labrador trough at Schefferville. Without the active cooperation of all of these scientists the field season would have been much less successful.

More detailed accounts of the areas visited with Windley, Westoll and Gandhi are in preparation and a joint paper comparing the shield areas of West Greenland and East Canada is planned with Drs F. C. Taylor and G. Jackson who are in charge of the GSC teams mapping in Labrador and Baffin Island.

\section{General comments}

Three main groups of Precambrian rocks were visited: older basement rocks, corresponding to the pre-Kelitidian complexes of Greenland, last metamorphosed about $2500 \mathrm{~m}$. y. ago; rocks of the Svecofennid and Hudsonian fold belts corresponding to the Ketilidian and Nagssugtoqidian fold belts of Greenland, which were metamorphosed at some time between 1400 and $2000 \mathrm{~m}$. y. ago; post-orogenic intrusions, lavas and sediments corresponding to the Gardar magmatism and sedimentation of South Greenland.

The geological evolution of the areas visited shows close resemblances to that described from Greenland and it would seem that future correlations in the North Atlantic Shield may be able to rely more on geological events rather than the system at present in vogue, which relies on the rather indiscriminate correlation of dissimilar rocks giving the same radiometric ages. While it would be unwise, and in the writer's opinion unnecessary, to correlate any particular supracrustal Group or Formation from area to area within the North Atlantic Shield, the general similarities both in types of sedimentation and in the subsequent plutonic development of different parts of the Shield are so marked that the various stages must mark fundamental changes in crustal environment. It would seem that the characteristic rock assemblages formed at particular stages in the crustal development can be classified according to the rules of lithostratigraphic nomenclature, although they are of much larger dimensions than those used for correlation in the Phanerozoic. In common with other lithostratigraphic units these rock suites may be diachronous. 
Specific points of possible application to the interpretation of Greenlandic Precambrian rocks

The character of the early basement rocks of eastern Labrador. Kenoran gneisses outcrop as a narrow slice along the east coast of Labrador from approximately $55^{\circ} \mathrm{N}$ to $59^{\circ} \mathrm{N}$ (Taylor, 1969). This strip is partly broken and updated by the emplacement of late Hudsonian anorthosites and rapakivi granites around Nain $\left(57^{\circ} \mathrm{N}\right)$. The gneisses show close similarities with the pre-Ketilidian rocks of Greenland, the main difference noted being the apparent lack of major early layered anorthosites. In the north the gneisses contain a high proportion of partly retrogressed granulite facies relics of supracrustal material. A repeated characteristic succession of ultrabasic, basic, quartzo-feldspathic and pelitic gneisses is seen in many localities and is interpreted as an original supracrustal succession comprising ultrabasic rocks ( ?lavas and sills), basic lavas, ?acid volcanic rocks and aluminous sediments. The granulite facies metamorphism is characterised by fairly high temperature - moderate pressure assemblages. The nearest equivalents to these rocks found in Greenland are the gneisses found in the high grade complexes north of Godthåb and perhaps in the supracrustal rocks in the Angmagssalik district. Their main interest to the interpretation of basement rocks in Greenland is the high proportion of supracrustal material preserved. This supports Berthelsen's (1960, p. 209) interpretation of the Tovqussaq area as largely supracrustal in origin. Further south, for example in the Fiskenæsset district (Windley, in press), the proportion of early supracrustal rocks preserved in the gneisses appears to be much smaller. A similar change is noted southwards in Labrador; in the Nain and Hopedale districts relics of recognisable supracrustal rocks in the Kenoran gneisses are rare. This suggests that there may be regional differences in the basement rocks of both West Greenland and Labrador, due perhaps to such factors as the level of the old crust now exposed or the amount of reworking the gneisses have passed through since their original formation.

General structure of the younger fold belts. The Svecofennid, Ketilidian and Labrador (Hudsonian) fold belts show similar gross structures. The marginal supracrustal rocks show an increase in metamorphic grade from zeolite or pumpellyite-prehnitequartz facies (Barager, 1967) where they overlie practically undisturbed basement, to a medium temperature and pressure metamorphism of Barrovian type where they abut zones of migmatite, syntectonic granite, and partially reactivated basement slices, some $50-100 \mathrm{~km}$ inwards from the margins of the fold belts. Supracrustal rocks found more centrally in the fold belts are not easily correlated with the marginal successions. They often show different metamorphic characters to those shown by the highest grade marginal rocks. Cordierite is a common mineral in the pelitic rocks suggesting a more marked thermal control of the metamorphism in these zones.

Two main features noted from the Svecofennid fold belt are of particular interest in the interpretation of the sedimentary environment and relative age of the supracrustal rocks found towards the centres of the Ketilidian and Labrador fold belts. Firstly detailed isotopic age determinations by $\mathrm{O}$. Kuovo (personal communication) have 
shown that boulders from the intraformational conglomerates of the Tampere schists were derived from gneisses and migmatites formed at an earlier stage in the development of the Svecofennid fold belt, and thus much of the sedimentary succession now preserved is later than the onset of regional metamorphism in the area. If the Tampere sediments are compared to the supracrustal rocks found towards the centre of the Ketilidian fold belt, for example those around Tasermiut fjord, then it would seem quite possible that the "basement" to this succession now suspected in the area between Nanortalik and Julianehåb may comprise both pre-Ketilidian rocks and migmatites formed at an earlier stage in the evolution of the Ketilidian fold belt. Secondly it has been recognised for many years in Sweden that the Svecofennid rocks contain a large number of acid volcanic rocks often with high soda contents. Reexamination of many of the Ketilidian "impure quartzites", from the southern tip of Greenland suggests that these rocks contain a much higher proportion of lithic tuffs than had been realised previously. While these rocks are commonest in the Tasermiut fjord - Kap Farvel area where they dominate the upper part of the supracrustal sequences, isolated patches of both acid and basic tuffs occur in the Nunarssuit and Julianehåb areas further to the north and it now seems possible that some of the sediments in the Ivigtut-Kobberminebugt area may contain considerable volcanic material.

The major development in Labrador of sediments thought by the writer to contain a high proportion of acid volcanic material is the $7500 \mathrm{~m}$ thick Aillik series of the Makkovik Bay area (Gandhi, Grasty \& Grieve, 1969). These consist dominantly of highly sodic impure psammites with intraformational conglomerates and layers containing what appear to be pumice fragments. The Aillik series is being extensively investigated for commercial deposits of molybdenum and uranium. Molybdenite occurs as a widespread ore mineral in the late Ketilidian calc-alkaline intrusions of South Greenland and may be presumed to have been derived from an original cover over these bodies. It seems that a search for economic deposits in the Ketilidian supracrustal series in the Kap Farvel area might be profitable.

The setting of the anorthosites of the Labrador coast. The petrology and mineralogy of the post-tectonic anorthosites of the Nain district (Wheeler, 1960) is almost identical to that of the inclusions brought up in Gardar dykes which were intruded some 300 m. y. after the emplacement of the anorthosites of eastern Canada and the rapakivi granites of both South Greenland and Labrador; assuming that the anorthosite inclusions in Gardar rocks are genetically related to their hosts then it appears that they must form an important link between the post-orogenic calc-alkaline suites of Greenland and the younger dominantly alkali cratonic magmatism.

\section{References}

Barager, W. R. A. 1967: Wakuach Lake Map-Area, Quebec-Labrador. Mem. geol. Surv. Can. 344. Berthelsen, A. 1960: Structural studies in the Pre-Cambrian of western Greenland. Part II. Geology of Tovqussap nunâ. Bull. Gronlands geol. Unders. 25 (also Meddr Gronland 123, 1). 
Gandhi, S. S., Grasty, R. L. \& Grieve, R. A. F. 1969: The geology and geochronology of the Makkovik Bay area, Labrador. Can. J. Earth Sci. 6, 1019-1035.

Taylor, F. C. 1969: Reconnaissance geology of a part of the Precambrian Shield, northeastern Quebec and northern Labrador. Pap. geol. Surv. Can. 68-43.

Wheeler, E. P. Ind 1960: Anorthosite adamellite complex of Nain, Labrador. Bull. geol. Soc. Am. 71, 1755-1762.

Windley, B. F. in press: The anorthosites of southern West Greenland. Mem. Am. Ass. Petrol. Geol. 12.

\section{A COMPILATION OF K/AR AGE DETERMINATIONS ON ROCKS FROM GREENLAND CARRIED OUT IN 1969}

\section{Bridgwater}

In order to relieve the pressure of routine work on the age dating laboratories in the University of Copenhagen and other institutes working in collaboration with GGU, it was decided to send out samples for K/Ar age determination by a firm of consultants*. The problems selected for study were generally of a regional character - for example the basic dyke chronology from SW Greenland - or were preliminary studies of rocks from areas where little isotopic age work had been carried out previously. Much of the material used was far from ideal for accurate determination of a particular event, the selection of samples having been controlled by geological criteria rather than the suitability for precise isotope measurement. The results are therefore to be regarded as pointers for future detailed studies rather than as having given definitive answers. Several of the determinations show the presence of excess argon, sometimes in considerable amounts. The possible geological implications of this are discussed briefly at the end of this note. The ages quoted are averages based on several determinations on each sample. Full analytical data is available on request from GGU. The constants used for calculation of the ages are

$$
\begin{aligned}
& \lambda_{\mathrm{e}}=0.584 \times 10^{-10} \mathrm{yr}^{-1} \\
& \lambda \beta=4.72 \times 10^{-10} \mathrm{yr}^{-1}
\end{aligned}
$$

* FM Consultants Ltd., 21 Harcourt Drive, Herne Bay, England. 